\title{
Assessing humour use in accommodation establishments: the Estonian context
}

\section{Marit Piirman}

University of Tartu Pärnu College, Estonia

marit.piirman@ut.ee

\section{Stephen Pratt}

The University of the South Pacific, Fiji

stephen.pratt@usp.ac.fj

\section{Melanie Smith}

Budapest Metropolitan University, Hungary msmith@metropolitan.hu

\section{Heli Tooman}

University of Tartu Pärnu College, Estonia heli.tooman@ut.ee

\begin{abstract}
This paper contributes to a relatively under-researched area of humour studies in hospitality by analysing the use of different forms of humour in accommodation establishments. The main purpose of the study was to gain a better understanding of how humour is used in marketing communication and service processes, and the ways in which it contributes to the guest experience. A range of research methods were used including desktop research on how humour is currently used in accommodation settings, a focus group consisting of international participants, and two online surveys with both accommodation providers and accommodation guests. The latter was undertaken in Estonia. The results indicate that multiple forms of humour are used in accommodation establishments to provide information and enhance the guest experience, however, it was also clear that many humorous events happen spontaneously rather than being planned for or 'staged'. This study also proposes a decision support model to guide accommodation establishments in how humour could be applied more effectively in their marketing communication and service processes.
\end{abstract}

Keywords: humour, tourism, marketing communications, accommodation, Estonia. 


\section{Introduction}

According to Wall (2017: 546) tourism should be fun and enjoyable, but using humour has sometimes been viewed as undermining the seriousness of the field. Research by Pearce and Pabel (2015) demonstrates that humour makes tourists' experiences more pleasant, unique, as well as memorable with enduring value. For example, humour use in tourism interpretation keeps tourist audiences engaged (Pabel \& Pearce 2016: 190-205). In today's fast-moving business environment, companies need to be able to innovate and use new approaches to entice customers and to differentiate themselves from competing firms. In the tourism context, this can be achieved through the co-creation of tourist experiences (Campos et al. 2018), which according to Slivar, Periša and Horvat (2018: 238-248) can be enhanced by using humour.

Accommodation is an important part of holidays, yet accommodation establishments are often considered just a place to stay for a few nights. Previous research shows that appropriate humour has a positive effect on tourists' intentions to revisit certain attractions or destinations (Pabel \& Pearce 2015: 357; Zhang \& Pearce 2016). Humour may have positive outcomes for accommodation providers by making stays more enjoyable and memorable. Yet the use of humour in accommodation settings has been relatively under-researched compared to other settings, e.g., tour operations and tour guiding (Pabel \& Pearce 2016; 2018).

Research on humour in tourism and hospitality settings has only started to emerge in the last decades. Johnson and Ball (2000: 16-29) wrote about the use of humour in hospitality, whilst Frew (2006: 643-646) offered a conceptualisation of humour tourists. The first book investigating the humour-tourism relationship was published by Pearce and Pabel in 2015. It outlines the multiple ways in which humour can be beneficial. However, the role of managers and staff members in creating humorous encounters in accommodation settings has been thus far under-researched.

The appreciation of humour in the marketing communication and service processes of accommodation establishments is a new area of research for the hospitality sector, as well as in the Estonian context where much of the primary data collection took place. The main aims of the research were therefore:

1) to analyse how humour is used in accommodation establishments and for what purposes,

2) to investigate how potential guests react to different forms of humour use in accommodation establishments and what they have experienced as guests,

3) to gain a better understanding of how Estonian accommodation establishments currently use humour in their marketing communication and service processes.

As well as contributing to humour studies in hospitality, the research also provides insights into the use of humour in a specific context (Estonia). The study of humour in different national contexts could offer fruitful comparisons for future studies. Furthermore, a decision support model is developed which could be used by accommodation providers to guide their use of humour.

According to Future Brand (2014), Estonia is currently not a well-known tourism destination. The slogan "Positively surprising" has been used since 2008 to promote the country to potential international tourists, however it is still unclear in what ways tourists might be positively surprised. From 2017, Estonia introduced a new brand concept, including several recommendations (including humorous ones) on how to promote this destination more effectively (Brand Estonia 2018). Tourism is an important sector for the Estonian economy and in order to enhance the accommodation sector's levels of differentiation, it is necessary to offer customers unique and memorable experiences. We argue that the use of humour may provide accommodation providers with an avenue to differentiate themselves from competitors. 


\section{Theoretical framework}

\subsection{Humour and its use in marketing communication}

Although humour is a universal phenomenon influencing all aspects of human life, it is hard to define what humour means. For some, humour is its physical manifestation: laughter. It can also be the comic, the ironic, the ludicrous; and it can be synonymous with wit or comedy. Despite the lack of a precise definition, humour research has attracted a multi-disciplinary and growing group of researchers and scholars to this uniquely subjective phenomenon (Raskin 2008).

Laughter, generated through humour, helps to release tensions (Freud 1905; Martin cited in Pearce \& Pabel 2015: 11-12). Humour can be an emotion regulator by which positive emotions can undo negative emotions (Samson \& Gross 2012). For example, it can provide a distraction from a stressful moment, and it allows people to see things from a different perspective (MacKinlay 2004: 43-58).

Carrell (2008: 2) theorizes that jokes are not inherently funny until an audience finds them amusing. People prefer humour that puts others down rather than themselves or their in-groups (Palmer 1994: 68). Humour could also be a tool to win an audience, unite them and be as catalyst of communication to break barriers between the superior and subordinate (Halim \& Razak 2014: 26). Effective humour delivery depends heavily on performance skills, the occasion, and relations between the one providing humour and the audience (Palmer 1994: 161-164). Friedman (2014: 5) confirms that comedy taste depends largely on cultural capital where the "most significant comedy taste division separates the 'highbrow' comedy taste of those with privileged cultural capital resources from the largely 'lowbrow' tastes of those with less cultural capital". The model by Martin and Ford (2018) on the different humour styles indicates that humour can be at your own expense or at somebody else's, and it also considers who is likely to benefit from humour in these cases (see Table 1).

Table 1. Four humour styles as a function of who benefits from the humour and at whose expense the humour is (reprinted with permission of Martin and Ford 2018: 122-123)

\begin{tabular}{|l|l|l|l|}
\hline \multicolumn{2}{|c|}{} & \multicolumn{2}{c|}{ Who Benefits from the Humor? } \\
\cline { 3 - 4 } \multicolumn{2}{|l|}{ Self } & $\begin{array}{l}\text { Relationships with } \\
\text { others }\end{array}$ \\
\hline \multirow{2}{*}{$\begin{array}{l}\text { At whose } \\
\text { expense? }\end{array}$} & $\begin{array}{l}\text { No one's expense: } \\
\text { Beneficial }\end{array}$ & $\begin{array}{l}\text { Self-enhancing } \\
\text { humor }\end{array}$ & Affiliative humor \\
\cline { 2 - 4 } & $\begin{array}{l}\text { Someone's } \\
\text { expense: } \\
\text { Detrimental }\end{array}$ & $\begin{array}{l}\text { Other's expense: } \\
\text { Aggressive humor }\end{array}$ & $\begin{array}{l}\text { One's own expense: } \\
\text { Self-defeating humor }\end{array}$ \\
\hline
\end{tabular}

Researchers categorize humour according to three major theories: superiority theory, relief theory, and incongruity theory (Lynch 2002: 423-445). The superiority theory pertains to humour involving one person's triumph over other people's weaknesses, stupidity or misfortunes because it makes them feel superior in some way (McGhee 1983: 109-134). The relief theory proposes that people laugh at things that make them feel uncomfortable or guilty (Smuts 2018). The incongruity theory presumes that people laugh at what surprises them, and at unexpected or odd events that present themselves in a non-threatening way. Some humour types use a mix of these theories (Pearce \& Pabel 2015: 10-12). Accommodation establishments are perhaps more likely to use incongruity mechanisms to surprise guests rather than other forms of humour that may make them feel uncomfortable.

Humour is used in several enterprises to accomplish important business objectives. For example, Slivar, Periša and Horvat (2018: 245) suggest that humour should be an essential 
element for Destination Management Organisations, especially when co-creating tourists' experiences. This might include, for example, the context of guided tours, where co-creation is rather common. Likewise, Pabel and Pearce (2018) advocate integrating humour into experience design thinking. For example, this can include humorous interpretation in attractions.

Humour in marketing and advertising works well with certain products. However, Chan (2010) argues that humour might be a distraction, which diverts attention away from the actual product. Birch (2011) states that the focus of advertising is on gaining attention and one of the best ways of achieving this is to use humour. However, the effectiveness of humorous appeal in advertising depends on the nature of the product, the target audience, and the content of the message (Šliburytė \& Klimavičius 2012). Whilst humour can be helpful in gaining people's attention, the advertised product or service has to be of high quality or customers are still not going to buy them.

When applying humour to mass media communication, marketers use it to attract attention and to entertain consumers, but they need to be careful not to inadvertently hurt someone's feelings (Warren \& McGraw 2013). Using humour is risky when content features highly controversial topics rather than non-controversial topics or when it targets specific people rather than people in general. This is especially important in a tourism and hospitality setting where the focus is on welcoming guests and making them feel relaxed and comfortable.

Sending and receiving humorous messages is highly dependent on the general communication process, where each message encoded by a sender needs to be decoded by the receiver of the message (Kotler, Wong, Saunders \& Armstrong 2005). Other factors can interrupt the movement of the message, so it does not reach the receiver in the way it was intended by the sender. Understanding the message depends on the sender's and receiver's experience, background, values, and many other characteristics. For the receiver to understand a humorous message as the sender intended, the message should be simple but not too simple.

There is considerable variability in terms of the medium used to 'transport' a humorous message, i.e. a story, a sign, a meme on social media. Berger and Iyengar (2013: 578) suggest that if the goal is to generate more online discussion, framing the product in an interesting or surprising way, then humour might be helpful. They note that ads or online content that surprise people, exceed expectations or evoke interest are more likely to be shared. Kotler, Jain, and Maesincee (2002) note that to make customers re-visit a website, aside from constantly renewing the content, interesting and useful content, jokes, competitions, and games could be useful. Appealing stories and videos that showcase the issue are not only good entertainment but are also powerful tools of communication (Kuosa \& Westerlund 2013: 181). Messages from a company are more easily accepted by customers if they have established emotional ties with the brand. This can, of course, include hotel chains, airlines or tour operators.

Humour is often used as a marketing communication method to draw attention to an advert and to motivate people to act (Brennan \& Binney 2010: 144-145). Positive emotions generated by humour increase positive brand associations (Strick, Holland, van Baaren, Knippenberg \& Dijksterhuis 2013: 32-69). Table 2 outlines ways in which humour might be applied as a communications strategy for accommodation establishments.

Table 2. Humorous message possibilities and their possible use as a communications strategy. Sources: LaFave (1972); Wilson (1979); Lynch (2002); Martin and Ford (2018); Neuendorf (2015); Samson and Gross (2012); Pearce and Pabel (2015)

\begin{tabular}{|l|l|}
\hline Humorous message & $\begin{array}{l}\text { Possibilities of using humour as a communications } \\
\text { strategy in accommodation contexts }\end{array}$ \\
\hline $\begin{array}{l}\text { Using humour at someone's } \\
\text { expense }\end{array}$ & $\begin{array}{l}\text { Communication has to be carefully planned to not } \\
\text { offend receivers, normally jokes would be at the expense } \\
\text { of someone that the client does not relate to }\end{array}$ \\
\hline
\end{tabular}




\begin{tabular}{|l|l|}
\hline $\begin{array}{l}\text { A puzzle or hidden joke that } \\
\text { requires the receiver to think }\end{array}$ & $\begin{array}{l}\text { A specially designed action or story that will culminate } \\
\text { in a humorous solution }\end{array}$ \\
\hline An unexpected result or surprise & $\begin{array}{l}\text { Explaining unique aspects of an accommodation } \\
\text { establishment that visitor would not understand or notice } \\
\text { otherwise }\end{array}$ \\
\hline $\begin{array}{l}\text { Using humour as a social } \\
\text { control mechanism }\end{array}$ & $\begin{array}{l}\text { A humorous sign or manual to explain how something } \\
\text { should be done }\end{array}$ \\
\hline $\begin{array}{l}\text { Using humour as a relief tool for } \\
\text { breaking the tension or to cope } \\
\text { with difficult or unexpected } \\
\text { situations }\end{array}$ & Humour in an interaction to solve a problem \\
\hline $\begin{array}{l}\text { Overcoming an unpleasant } \\
\text { situation }\end{array}$ & Explaining shortcomings with humour \\
\hline
\end{tabular}

\subsection{Humour in tourism and hospitality services}

Travelling allows people the possibility to escape their daily routines and stressful lives. The tourism sector is oriented towards making people happy (Pearce \& Pabel 2015: 24). According to Ball and Johnson (2011: 199, 202) early travellers were considered as a threat to some local communities and humour was often applied as a critical method to reduce tensions. Hosts in early hotels used humour to convert strangers into friends. In the hospitality sector, humour has been associated with friendliness and enhancing the wellbeing of all parties involved when providing food, drink, and accommodation.

Based on previous academic literature, Frew (2006: 643-646) conceptualises informal and formal humour in tourism. She separates humour into two main areas of the tourist experience. Firstly, informal humour in the form of sharing jokes during difficult, awkward or frustrating travel situations, and secondly, formal humour which occurs when people attend comedy festivals and/or comedic TV and film locations. Comedy festivals represent a pull factor for many tourists. Frew uses the term "joke junkies" to describe people who travel in search of humour.

After collecting data from 541 visitors from adventure tourism settings in Australia, Pabel and Pearce (2015: 360-363) classified humour provided for tourists into five categories: enhancing interest/attention; breaking the ice/bonding; creating entertainment/fun; alleviating anxiety; and lightening the mood. They state that an effective use of humour by tourism operators can lead to advantages because it has the potential to create potential repeat visits, to extend periods of stay at attractions, to foster positive word of mouth recommendations and to add a more professional image to a company.

Pearce (2009: 19) suggests there are multiple patterns and pathways to create humour in tourism settings and that its outcome depends on the delivery skills of the source, the humour appreciation of the target and the technique type and medium chosen to present the humour. The model presented in Figure 1 shows the three outcomes successful humour delivery can achieve: to establish comfort levels; to boost concentration; and to form a connection with tourists and their presenters. In extending the model by Pearce (see Figure 1), we argue that there is potential to include unintentional or accidental forms of humour as a technique type. Based on the data collected for this study, another addition to this model is the compensation outcome of humour, which is explained further in the results section of this paper. 




Figure 1: Tourism and humour: Patterns and pathways (adapted from Pearce 2009)

Depending on the effectiveness of the humorous delivery, the outcomes of humour can either be positive and beneficial or negative and detrimental. Therefore, it is important to ensure that humour delivery is appropriate for its tourism setting and audience (Pabel \& Pearce 2018: 6470). Benefits for tourists of using humour during their travel are: breaking the ice with strangers; dealing with overcrowded places and awful food; making the best of a situation gone wrong; lightening the mood; comforting others; alleviating anxieties; resolving conflicts and coping with difficult and embarrassing situations (Pearce \& Pabel 2015; Samson \& Gross 2012). Laughter facilitates social bonding and social cooperation particularly among strangers (Van Vugt, Hardy, Stow, \& Dunbar 2014: 28).

Some negative outcomes of humour include irritation and annoyance, particularly when humour is overused or not relevant to the context in which it is presented (Pearce \& Pabel 2015). Gáll (2011) investigated accidental humorous cases posted online based on Raskin's semantic script theory of verbal humour. In most cases, the translations failed to capture the nuances of the English language, some of which were still unintentionally humorous. For Gáll, this raises the question of when miscommunication stops being humorous and starts becoming irritating, particularly to native speakers.

Research conducted by Seneviratne \& Molesworth (2015: 130-135) among 45 university students reveals that using humour in the pre-flight safety briefing videos is most effective in maintaining a participant's attention as well as helping passengers recall key safety messages. Research undertaken about guest experiences in Turkish boutique hotels shows that, in addition to service quality, one of the aspects that created a positive impact on customer satisfaction was the humour created by the hotels' employees (Kurtulay et al. 2015: 45). Table 3 outlines the marketing mix elements that play a role in the tourism-humour nexus. 
Table 3. Marketing mix elements and their relevance to the tourism-humour relationship Sources: Ball and Johnson (2011); Van Vliet (2013); Pearce and Pabel (2015)

\begin{tabular}{|l|l|}
\hline $\begin{array}{l}\text { Marketing mix } \\
\text { element }\end{array}$ & Role in the tourism-humour relationship \\
\hline Product & Tourism experience offers customers a chance to smile/laugh \\
\hline Price & $\begin{array}{l}\text { Amusing price offers when bundling certain tourism experiences; } \\
\text { humorous number combinations that attract attention }\end{array}$ \\
\hline Place & $\begin{array}{l}\text { Considers the place/settings in which the humour is presented, i.e. } \\
\text { danger, safety, fun, mild message, strong message }\end{array}$ \\
\hline Promotion & $\begin{array}{l}\text { Ways of promoting a tourism business using humour, i.e. announcing } \\
\text { humour in any marketing collateral to build curiosity about a tourism } \\
\text { experience }\end{array}$ \\
\hline People & $\begin{array}{l}\text { Source of humour, i.e. tourists, tour guide/entertainer, and the target } \\
\text { audience, i.e. tourist market segment, locals, employees, general } \\
\text { audience }\end{array}$ \\
\hline $\begin{array}{l}\text { Physical } \\
\text { evidence }\end{array}$ & $\begin{array}{l}\text { Staff wear amusing uniforms/accessories, i.e. Mickey Mouse ears; } \\
\text { interior and exterior design, i.e. signs on the walls, statues, decorations, } \\
\text { etc. }\end{array}$ \\
\hline Processes & $\begin{array}{l}\text { Processes involved in delivering tourism services to the customer, i.e. is } \\
\text { it easy and enjoyable to do business }\end{array}$ \\
\hline
\end{tabular}

In regard to the product element outlined in Table 3, it needs to be acknowledged that much of the humour used during tourism experiences is highly scripted based on what has worked in past customer interactions. For example, in adventure tourism settings, humour is often used to help alleviate anxious feelings (Pearce \& Pabel 2015: 359). Although money is not something people often joke about, humorous pricing can occur accidentally with respect to price tags and unusual price combinations can attract attention. With respect to the place element, Zhang and Pearce (2016: 259-271) identified that humour can play an important role in portraying the distinctiveness of a place or destination. The role of humour for promotion purposes works well for many tourism businesses. The study by Pabel and Pearce (2015: 363) illustrates that some tourism operators announced their use of humour in their marketing collateral, which often builds curiosity amongst tourist audiences.

People play a vital role in the creation of humour, with individuals who can make others laugh often regarded as valued company (Martin 2007: 10). Hotel employees' intellectual capital and their emotional labour have been shown to create value in interactions with tourists (FitzPatrick, Davey, Muller \& Davey 2013: 86-98). Similarly, Ball and Johnson (2011: 202-204) use TGI Friday's, a restaurant that utilizes humour in every aspect of its business operation as an example, to show the benefits of humour for both staff and guests. TGI Friday's waitresses and waiters are encouraged to wear funny clothes and accessories. Humorous signs can be part of tourism interpretation, which also represents an example of physical evidence. Other examples in this category include the quirky livery of some airlines, i.e. Kulula Airlines in South Africa. Process refers to the processes involved in delivering a tourism service to the customer. This 
element considers how easy and enjoyable it is to do business. The mood of all parties involved in a transaction has an impact on how processes are perceived. For example, Sirakaya, Petrick, and Choi (2004: 532-535), found in their study conducted on cruise ships that tourists who were in a bad mood gave lower ratings for satisfaction. Therefore, ensuring that customers are in a good mood should also have benefits for tourism businesses, i.e. enthusiastic staff members. Disney is a good example of a company that builds their processes on positive emotions (Bryman 2003: 100).

As the presented literature shows, humour has been studied in a variety of settings, i.e. restaurants, tour guiding and cruise ships. However, there is very little academic literature about humour in accommodation establishments. Ball and Johnson (2011: 208) suggest that humour is relevant to hospitality workers because it helps to cope with failure, criticism and stress that often occur due to long working hours, unusual shift arrangements, stressful conditions and monotonous work. To study humour usage in accommodation establishments, the links between humour, tourism and hospitality and marketing communications have to be considered.

\subsection{Overview of the Estonian accommodation market}

The accommodation sector in general and specifically in Estonia has become more competitive. In 2014, there were 570,000 tourist accommodation establishments in the European Union (EUROSTAT 2018). According to the Republic of Estonia Ministry of Economic Affairs and Communication (2014), there were about 1,600 accommodation enterprises in Estonia, offering more than 40,000 beds. The economic situation is challenging for many official accommodation establishments in Estonia due to the increasing competition from additional accommodation options offered via sharing economy platforms like Airbnb.

Estonia has been promoting itself with the slogan "Positively surprising" for several years. American writer Alexander Theroux labelled Estonians as glum and sour-faced (Murphy 2011). Nevertheless, Estonia has made several attempts at using humour to entice visitors. For example, the tourism information homepage of Hiiumaa, a small island on the West coast of Estonia, says that the most important thing is to have a sense of humour and that people of Hiiumaa love jokes (Hiiumaa Tourist Info Center 2015). According to the Estonian writer Viivi Luik, much of the Estonian sense of humour is based on mockery, irony and self-irony (Magic Unica 2018). The Estonian sense of humour is dry, sarcastic and quite often politically incorrect. In Europe, the Estonian sense of humour is most similar to British humour, but it is blacker than that of the English. Gallows humour is well accepted, and jokes at one's own expense are popular. However, you are much more likely to get a grin, not open laughter as a response (Visit Estonia 2015). Even the Lonely Planet covers the Ancient Estonians' cruel sense of humour, explaining that when Estonian warriors promised not to raise swords against enemies, they used stones to attack instead (Dragicevich, Ragozin \& McNaughtan 2016). Chłopicki and Laineste (2019) found that even the usage of adjectives and adverbs communicating positive evaluations are rarer among Estonians than, for example, Polish people.

Given the importance of the Estonian accommodation sector and the potential benefits of using humour in their communications, this research was undertaken in an Estonian context. The research contributes to current tourism humour theory by considering whether humour can reveal to tourists "insights into the country, its citizens and its locations" (Zhang \& Pearce 2016: 270) in the Estonian context but also helps to understand humour in tourism better.

\section{Methods}

Humour studies are often conducted in isolated so-called laboratory conditions, where research participants are subjected to various humour stimuli (Palmer 1994: 70). However, Pearce (2009: 
633) took humour research into the field by analysing cases and collecting archival materials on tourist attractions. Pabel and Pearce (2015: 358-359) also conducted surveys and group interviews. Since humour in the tourism and hospitality sector is a rather exploratory topic, a mixed methods approach was taken to answer the research objectives of this study. Data collection was undertaken from October 2015 to January 2016.

The first research objective is to determine how humour is currently used in accommodation establishments. To address this objective, the research process started with a desktop research, which entails extensive internet searching to gain initial understanding of a topic. Keywords such as "humorous hotels", "funny hotel", "funny hotel signs" were entered into different search engines, i.e. Google Images and Pinterest. These keywords allowed the researchers to gain a better idea of the kinds of amusing videos, photos, and signs that people post online. In addition, photos and brochures collected by the authors and their colleagues were gathered over the years. Visual material was used in the focus groups to understand the humour responses of people from different nationalities and to ascertain how people with different cultural backgrounds perceive humorous communication from hotels.

The second research objective is to better understand what kind of humour accommodation guests have experienced in accommodation establishments and to determine how respondents perceived the humorous communications provided by accommodation establishments. An online survey was used to address this research objective. Given the global presence of Facebook, the survey was distributed through this social media platform. Respondents were recruited through snowball sampling and by sharing the link to the online survey in an Estonian newspaper. Snowball sampling was used with the purpose of gathering as much data as possible from people with different experiences and backgrounds. The snowball sampling process started with the first author sharing the link of the survey with her online networks by asking them to a) complete the survey and b) forward the survey link to other possible respondents. Survey questions were created based on humour and communication theories noted in the literature review section. On January $30^{\text {th }}, \quad 2016 \quad$ a $\quad$ public $\quad$ Facebook group https://www.facebook.com/pg/huumorturismis/posts/?ref=page_internal was established with the purpose of distributing the questionnaire and asking members to post humorous photos and stories of their travel experiences. The accommodation establishments' guest survey yielded 54 responses: 44 from females and 10 from males. The average age of survey respondents was 35 years old with the youngest being 18 years old and the oldest respondent being 67 years old. It should be noted that the sample is highly influenced by the first author's network and acquaintanceship, and it is well known that social media (e.g., Facebook) tends to be used by a younger demographic. It is acknowledged that the sample is not representative in terms of its sample size and the sampling method, therefore, it is not possible to generalize the results to the larger population of domestic travellers visiting Estonian accommodation establishments. Nevertheless, the results offer valuable insights into what accommodation establishments should consider when applying humour strategically in their marketing communication. In order to expand the accommodation establishment guest survey, analyses of 40 funny travel stories collected by the first author during several workshops in two universities (in Estonia and in Finland) during the period of 2016 to 2019 were included.

The third research objective aims to gain a better understanding of how Estonian accommodation establishments currently use humour in their marketing communication and service processes. To discover how Estonian accommodation establishments deliberately use humour in their marketing and general communications, a survey among accommodation establishments was undertaken. A list of Estonian accommodation establishments was obtained from Visitestonia.com, a webpage that shares information about different tourism offers in Estonia including contact details of various accommodation establishments. The online survey was sent to the email addresses of 1,203 different accommodation establishments, with a follow- 
up email sent one week after the initial email. A total of 194 responses was received which indicates a response rate of $16.1 \%$. The sample characteristics suggest the sample is representative.

Most answers came from holiday homes (26\%), followed by guesthouses (19\%), hotels (16\%) and bed and breakfast establishments (16\%). 127 respondents were situated in rural areas and 67 in urban areas. The data was entered into SPSS for analysis. The analysis in SPSS involved calculating and reporting descriptive statistics of the Estonian accommodation establishments' survey. Several open-ended questions were used with the purpose of allowing respondents to share their thoughts freely about humour in accommodation establishments. These open-ended responses were subjected to manual content analysis by looking for common themes.

\section{Results}

\subsection{Findings from desktop research and focus groups}

The desktop research results were used to address the first research objective, which focused on determining how humour is currently used in accommodation establishments. The desktop research formed the basis and framework for the primary data collection and also allowed international comparisons for the subsequent Estonian data. Based on the selection of photos collected, it was established that accommodation establishments use humour predominantly in their signage, and to a lesser extent in their room amenities.

A good example of how humour is used effectively in the hotel context is 25 hours Hotels. Their business concept appears to be built on being professional whilst being quirky and funny at the same time. Each hotel within this chain showcases their humorous flair using different design elements. For example, one hotel has pillowcases with the message: "Let's spend the night together", another uses toilet bowls that look like the shape of a mouth.

Other hotels show their sense of humour with funny "do not disturb" door signs: "I'm in here. You're out there. Let's keep it that way a while longer." or using laconic "Not now" rather than "Do not disturb" signs. The latter is a rather negative statement so positioning this statement in a humorous way softens its delivery while still communicating the message.

Nordic Choice Hotels have an amusing, yet informative booklet in their rooms, explaining through humour how easy it is to be sustainable and use fewer resources (see Figure 2), why it is better to be a vegetarian, saying that "Real cowboys eat what the cow eats", and explaining how to exercise in a small hotel room by using comic strips. Instead of elevators, they have signs next to the stairs saying: "All our hotels have installed eco elevators. Give yourself a lift, take the stairs." Sustainability values are therefore shared through humour. Humour can also be used in design elements as the Scandic Hotel has done (see Figure 3).
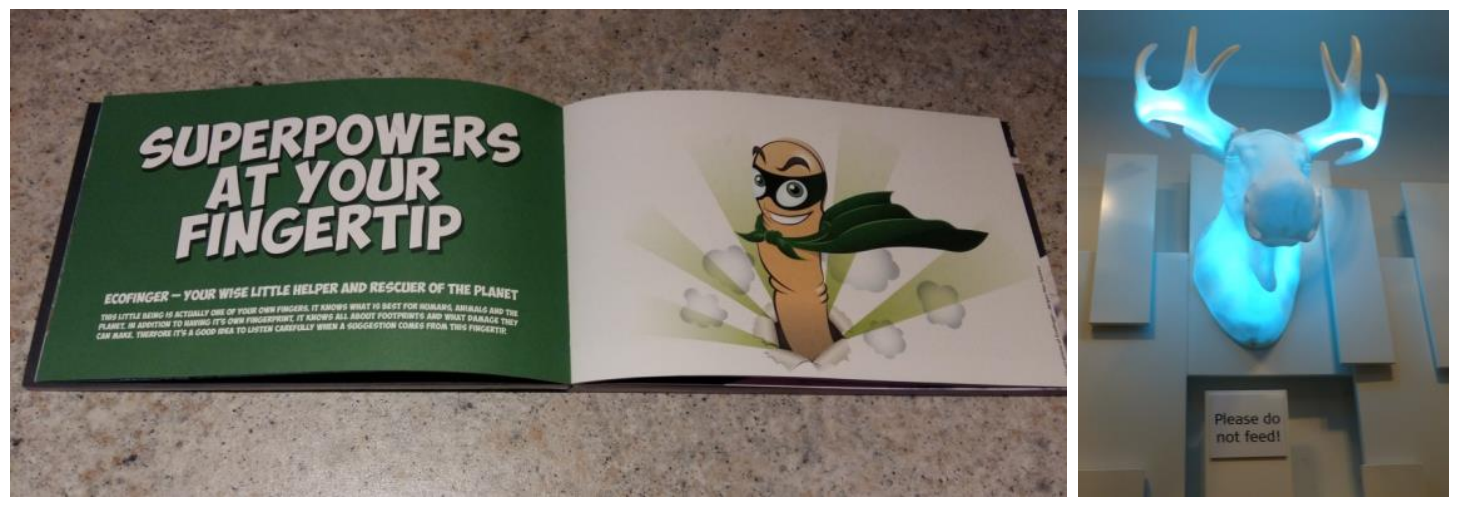

Open-access journal | www.europeanjournalofhumour.org 
Figure 2. Booklet showcasing information about saving natural resources "Superpowers at your fingertip"

Figure 3. Moose head shaped lamp with a sign "Please do not feed!"

Source: authors

A selection of humorous photos $(n=10)$ collected during the desktop research was shown to focus group participants consisting of international postgraduate students at an Estonian university in order to evaluate how cultural background influences their appreciation and understanding of humour. The photos were chosen with the purpose of offering a variety of different humour styles and of covering the content of humour in Pearce's Tourism and humour: Patterns and pathways model (see Figure 1). However, a different set of images may result in different findings. We acknowledge that the demographic composition of the focus group can affect the group discussion. As Friedman and Kuipers (2013: 192) say, people from different social groups may dislike other people's taste in humour but they will not subvert other's cultural hierarchies. Nevertheless, focus group participants varied by gender and cultural background. The focus group moderator was experienced in eliciting responses from all focus group participants. With consent from participants, the focus groups were videotaped and re-watched with the researchers noting themes, keywords and quotes until the data were thoroughly synthesized.

Focus group participants perceived half of the presented photos as humorous. However, some of the focus group participants also made several unexpected statements about the photos. For example, some of the participants held strong religious beliefs and were offended by some of the innuendos and risqué references in the visual materials - elements which other participants found rather amusing. The photo of the mouth-shaped toilets was perceived as inappropriate instead of funny by several people, yet there were also opinions that the design is well chosen, thought-out, cheeky and could be qualified as smart humour. Men and women had different opinions regarding the sexist aspect of the photo. Another example was the useable souvenirs provided by Protea Hotels, some of which include humorous sentences (pack of condoms with the sentence: "Unexpected guest?" and box of matches saying "Pyromaniac help line 0829026046 "). These images resulted in an interesting discussion, where focus group participants were trying to decipher the intended messages the hotel wanted to communicate to its clients. The idea of the condom package was mostly considered funny, but one participant admitted she does not like sex-related jokes or to discuss topics like these in public. There were also ethical and moral issues with a photo of a hotel billboard that said "KINGS MANSION Having an Affair? Do it Here! For reservations CALL 255-4647", describing it as low level, not funny and even shocking. Participants seemed to be confused by this photo, asking whether it is even real. The line between amusing and offensive was considered to be thin.

A photo of a hotel soap package saying "this is the cutest soap that you will steal from a hotel: enjoy it" caused a heated discussion that the message is funny, but it can be also offensive for some guests, since stealing is not considered the right thing to do, yet many people take 'souvenirs' from hotels. The question arose as to why hotels would assume that people steal. A picture of a sign saying, "Do not wash your feet in a toilet" was amusing but also confusing for students with European background, but one Muslim participant explained that washing one's feet is important for praying and sinks are too high.

Another group of photos that was evaluated as somewhat funny were the admonishing messages displayed humorously, for example: "Enjoy our complimentary fresh air. Our hotel is now 100\% smoke-free" and "In case of fire, exit building before tweeting about it". Presenting important information humorously was considered a useful approach by the participants who also commented that messages like this will definitely be remembered. 
The focus group discussions reinforced the fact that different cultural backgrounds, religious beliefs, but also genders play an important role in how people perceive humour. Hence when using humour in accommodation establishments, these types of aspects need to be considered.

\subsection{Results of the accommodation establishment guest survey}

Respondents of the online survey shared 47 examples of their own funny travel experiences that occurred during their travels. Humorous travel stories were categorised as: situational comedy, humorous hospitality staff, and unexpected events.

Situational comedy was mostly linked to the misfortunes of people mentioned in stories. Example comments include accidentally leaving some family and group members behind, hurting themselves, trying to find bathrooms, missing or almost missing a plane/boat, accidently losing their clothes or walking into a bathroom meant for the opposite sex. Many of the reported humorous events concerned bathrooms/toilets or the lack thereof. One man noted a sign in a toilet saying: "It is not as long as you think it is, so step closer, please!" Sex-related humour was also mentioned in the context of situational comedy. Some respondents stated they were unable to sleep because of the thin walls between rooms or they could not enjoy intimate moments to themselves because of interruptions by a local hotel 'ghost'. Overall, it was clear that people remember and want to share stories that were humorous.

The category of humorous hospitality staff was based on misunderstandings between the host and the guest derived from either language or cultural differences. For example, ordering alcohol with ice cream instead of ice or ordering milk instead of coffee with milk. Survey respondents also provided examples of when they overheard conversation between hotel employees and guests such as two gay men wishing to check into a room where they could sleep in the same double bed rather than two single beds. Another example describes a situation where a man wanted to show that his food was delicious by rubbing his stomach. This gesture is used mostly by children to express satisfaction with their food. However, in this case, the waitress must have been unaware of this meaning and started to clean the man's shirt.

Many of the positive humorous interactions with hospitality staff that respondents recalled were of the planned/scripted kind. For example, one guest who requested a wake-up call because he often slept through his own alarm, was woken up by the receptionist singing to him through the door. In another instance, a waitress seeing that guests looked tired and in need of some cheering up, served the child a glass of beer and the father a soft drink, making both guests laugh at the obvious mix up.

In the category of unexpected events, a frequent yet unfortunate source of humour was when the accommodation establishments' service was considered so poor that the only way to cope with the situation was by re-telling the experience in a humorous way. Examples include survey respondents noting false advertisement on a webpage; a drunk front-desk employee causing humorous situations or an incident where a guest was accused of stealing from the hotel room. Altogether twelve respondents recalled unpleasant experiences that they turned into an amusing story. Respondents also noted that negative events were easier to remember than positive ones. Some respondents also stated that they were unwilling to stay at those places again where a funny situation occurred, due to their negative experiences.

Two-thirds of participants considered having a humorous experience during their travel as either very important or important. A large proportion of those who had humorous experiences at hotels (either positive or negative) stated that they shared their amusing experiences with friends and relatives or by writing about their experiences on social media platforms.

To compare stories provided by Estonians to those of the international respondents, several Estonian answers were related to bad service turning into an amusing story, whereas only two international respondents remembered a funny story related to lack of service quality. Stories 
shared by international respondents could be classified under the category of using humour to cope with difficult or unexpected situations and using humour to overcome an unpleasant situation.

\subsection{Results of the accommodation establishments' survey}

The findings from the accommodation establishments' survey revealed that more than half ( $56.7 \%$ or 110 out of 194) believe that humour should be used in accommodation establishments. $87 \%$ of the survey respondents stated that they have used humour in their organisation. The most commonly stated reason for using humour was: humour is an important part of life; they acknowledged that many guests came to have a good time; they enjoyed the process of making people smile/laugh; they stated that humour helps to relieve tensions and aids in connecting with people. For example, humour can be used to explain serious topics about Estonian history, to explain shortcomings, to make communication 'lighter', to make people talk about the place, and to motivate workers.

There were also those respondents who answered that humour should not be used. One accommodation provider stated that she disliked people trying to make a joke. Another respondent stated that humour has no place in advertising because people are looking for trustworthy and precise information.

Accommodation establishments were asked in what ways they communicated humour with their clients. One-on-one communication between an employee and the customer was stated as the most relevant channel to communicate humour, followed by humorous souvenirs/keepsakes and humorous signage, i.e. cartoons.

The open-ended questions revealed that many accommodation establishments have humorous stories that they use to entertain guests. One accommodation provider has a tiger skin hanging on the wall of their rural guesthouse. When clients ask about it, the hostess tells them a story about an incident that happened years ago when some animals escaped from the Tallinn Zoo and the tiger was captured on their property. While the story is not true, it still captures the attention and imagination of their guests.

Several accommodation establishments use humour in the interior and exterior of their establishment, i.e. signs. One respondent commented that his town hostel had a button on the wall with a sign "Pointless Button". Funny signs in saunas use visual ways of instructing guests on how guests should use them. Another accommodation establishment uses a sign with a slogan that says: "In the winter, storehouses are used for storing crops but in the summer, they are used for storing tourists".

Guests' reactions to humorous communication were, according to accommodation establishments, mostly positive. Even though most responses indicated that guests are made to feel happy and positive, an important factor in communicating humour focused on generating positive word of mouth. However, there is always the possibility that any humour is not understood or appreciated due to the subjective nature of humour. In today's world of increasing political correctness, some people are rather sensitive, and it can often be challenging to use humour without offending. It is also important to take cultural and religious differences into consideration, especially given the increasing number of travellers from regions where language knowledge may not be sufficient to really understand complex verbal humour.

Some accommodation establishments voiced concern over using too much humour in hotel advertising since this might create a situation where guests arrive with high expectations of being amused. However, several respondents said that humour helped them to solve problems or deal with challenging customer situations. The survey also prompted the Estonian accommodation establishments to include photo examples of how they deliberately used humour. A total of ten photos was received from Estonian accommodation establishments indicating a variety of ways 
in which they used humour. For example, the image in Figure 4 sends a clear message through humour that whining and complaints are not appreciated. However, some guests may not appreciate this message, as it implies that the hotel is not willing to deal with problems.

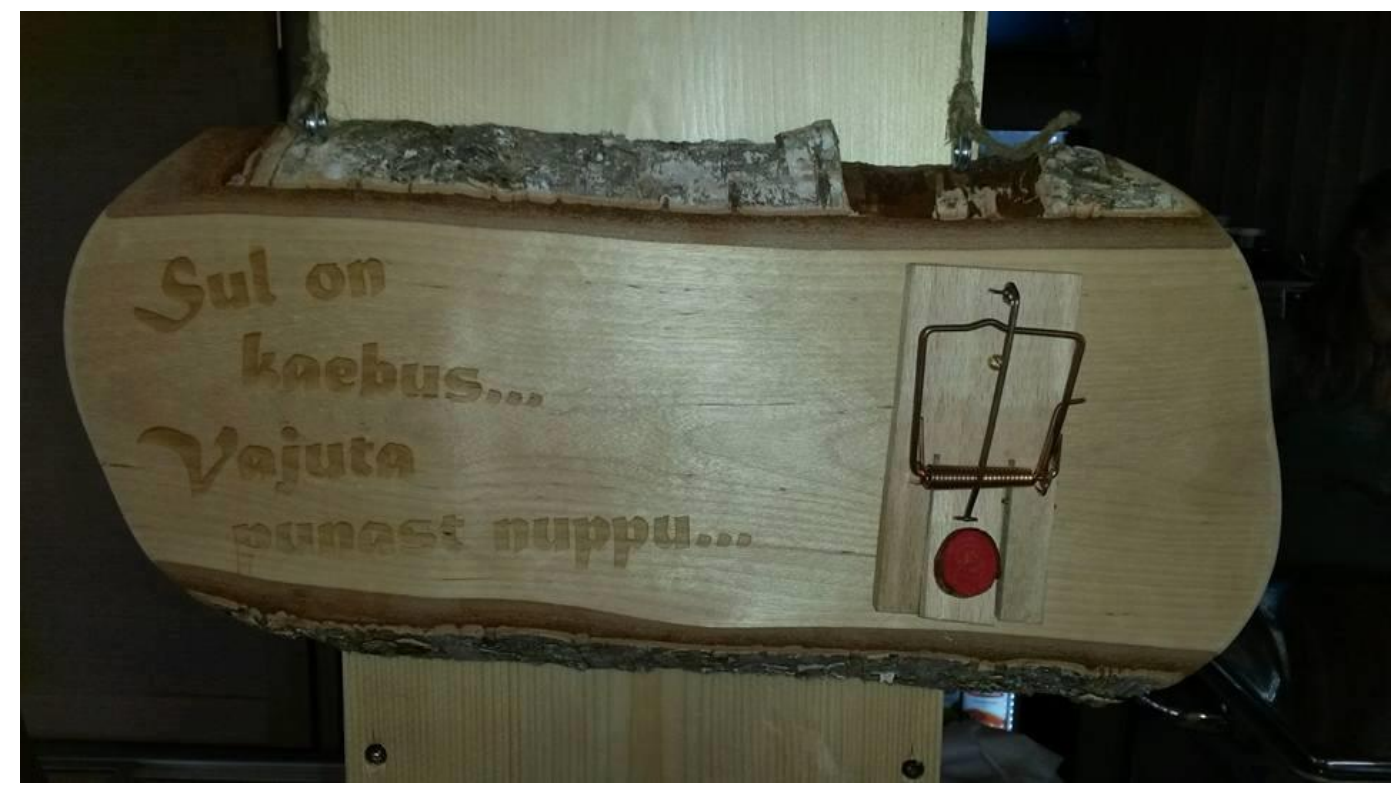

Figure 4. "You have a complaint... Press red button...". Source: authors

Another example was provided by a hotel with the highest quality service standards, which decided to send an amusing postcard to their regular customers and partners showing hotel workers relaxing on the beach covered with snow (see Figure 5). This humorous act of kindness gives the receivers of the postcard a possibility to reminisce about the enjoyable time they had during summer. It may also make them appreciate the hotel's employees, who are busy working for them while they enjoy the beach in summer, but can only take their holidays in the low season.

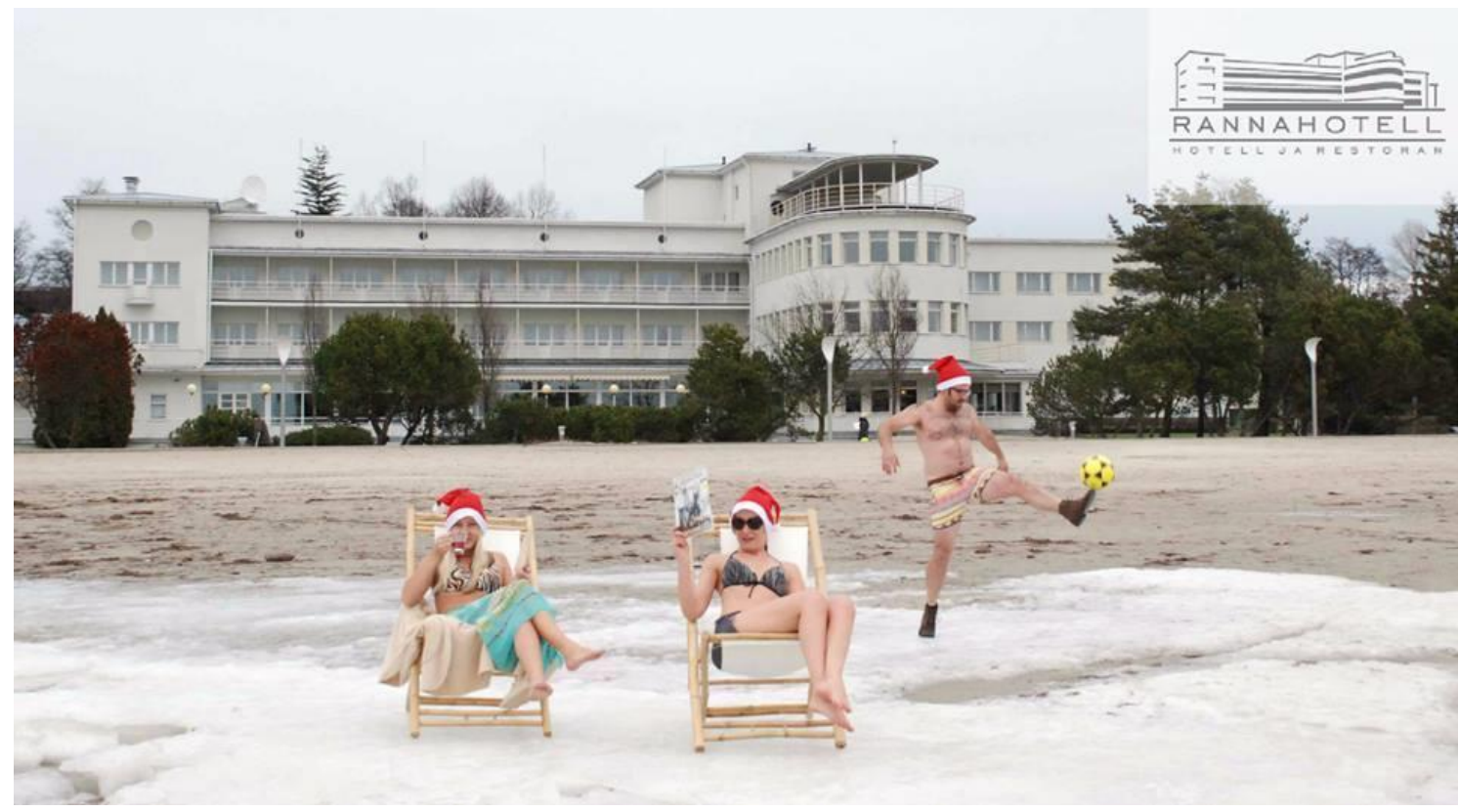

Figure 5. Beach hotel's Christmas card. Source: authors

Other photo examples included an image of a sign next to the bathroom mirror saying: "It's better to be late than to arrive ugly"; a photo of stuffed animals having a feast; a cartoon of a 
tired tourist arriving at their premises; and a funny April Fools' Day advertisement. Two respondents sent stories about how they humorously entertained their customers and received positive feedback.

\section{Discussion}

This paper set out to study the use of humour in accommodation settings, a topic which has not received much attention in the tourism literature. Few studies have been conducted in the field on the deliberate use of humour in businesses. Some may perceive hotels and other accommodation settings as places where serious business transactions take place, with no room for humour and laughter (cf. Ball \& Johnson 2011). These thoughts are likely to change as client opinions are shifting and businesses must keep up with the latest customer trends if they wish to be competitive. On the other hand, the research demonstrates the need to be culturally and linguistically sensitive.

The research conducted for this article shows that there are several accommodation establishments which use humour in their operations. Our study also shows that a number of accommodation establishments used humour to solve problems, yet most of the stories that accommodation guests perceived as amusing related to problematic customer situations or bad service. This concurs with the research by Samson and Gross (2012) who explained that positive humour is related to the reappraisal of the situation, but negative humour helps to create an emotional distance from the negative event. If accommodation establishments are in fact aware of their own weaknesses and shortcomings, then humour could potentially be used as a strategy to let clients know about those shortcomings in order to avoid disappointment at a later stage. Hence humour can be used as a compensation strategy. This is where this study contributes to Pearce's (2009: 19) model in Figure 1. Apart from the current outcomes of comfort, concentration and connection, we argue another outcome of humour is compensation, which adds a fourth $\mathrm{C}$ to the model. It needs to be acknowledged that humorous approaches to solving problems may work only with minor shortcomings and only with certain guests. In general, guests will expect serious problems to be solved. However, it may not always be possible to anticipate problems or negative experiences. This study has shown clearly that many of the respondents' funniest travel experiences happened spontaneously and were not planned or staged by a tourism or hospitality operator. Nevertheless, retrospective compensation is still possible on the part of a venue in which the experience takes place.

Pearce and Pabel (2015) classified the benefits of humour for tourists into five categories: enhancing interest/attention, breaking the ice/bonding, providing entertainment/fun, alleviating anxiety, and lightening the mood. Our study found similar results for accommodation settings (see Table 4). This means that even though accommodation establishments are static and their offer is stable (i.e. there are fewer opportunities for co-creation of experience), the benefits to accommodation guests are similar to those perceived by tourists who are taking part in general tourism experiences, i.e. guided tours.

Table 4. Classification of humour in tourism sector in general vs. accommodation establishments

\begin{tabular}{|l|l|}
\hline $\begin{array}{l}\text { Benefits of humour in tourism } \\
\text { (Pearce \& Pabel 2015) }\end{array}$ & $\begin{array}{l}\text { Results from accommodation establishments- } \\
\text { based survey }\end{array}$ \\
\hline Interest/attention & To be remembered; to attract attention \\
\hline Breaking the ice/bonding & To create interaction; to gain trust \\
\hline Entertainment/fun & To generate positive emotions \\
\hline
\end{tabular}

Open-access journal | www.europeanjournalofhumour.org 


\begin{tabular}{|l|l|}
\hline Alleviate anxiety & To reduce pressures/stressful situations \\
\hline Lighten the mood & To deal with minor weaknesses/shortcomings \\
\hline
\end{tabular}

A major contribution of this study is the development of a decision support model that is inspired by the Design Ladder (Danish Design Centre 2015). The model uses a step ladder approach to show the different levels of how humour could be applied to accommodation establishments (Figure 6). It brings together findings from the desktop research and the accommodation establishment survey.



Figure 6. Decision support model for humour usage in accommodation establishments

The lowest level of the ladder is about situational humorous communication that is provided by the employees of accommodation establishments and is largely situation-dependent. This type of humour is likely to occur spontaneously during interactions between employees and guests or between the guests themselves. Situational humour often requires a good sense of humour from both parties.

The second level of the ladder is based on hidden humorous communication that is understood and appreciated if guests are attentive and observant to notice small details and have the appropriate background knowledge to solve any incongruities. An example could be a chandelier made from silverware in a high-class luxury hotel, a funny-looking figure or a sign.

The third level of the ladder represents intended humorous communication, which is based on pre-planned or scripted uses of humour in the interactions between accommodation employees and guests. For example, many Estonian accommodation establishments have a long and interesting history and stories connected to the building or to its previous inhabitants. Amusing stories can easily be combined with services or become a platform from where new products and services could be developed. Humorous responses to minor weaknesses and problems may work. Unintentional humorous communications could therefore be helpful in drawing attention to any shortcomings that need to be fixed for customers or in explaining temporary gaps in service. For example, there was a bad internet connection at one of the rural bed and breakfast providers and the owner used a joke to explain it: "If you have seen the mobile company's advertisements where they promise 99\% of coverage anywhere in Estonia, then at this moment you happen to be in the $1 \%$ area". Nevertheless, to attract and satisfy future guests, accommodation entrepreneurs have to ensure quality service delivery. 
Level four, designed humorous communication, includes the use of humour that is designed to be part of the interior and/or exterior servicescape elements of accommodation settings. Examples from this study include Figure 2, which provides information about how to save natural resources in a humorous way; or Figure 4, which is a humorous way of indicating that complaints are not appreciated. This also includes designed activities researched by Pabel and Pearce (2018). There is a fine line between hidden humorous communication and designed humorous communication because both could consist of funny and amusing art, decorations and other design elements, which are likely to be noticed only by observant guests who take the time to look around and read information booklets.

The top level of the ladder is promised humorous communication. In these cases, humour is promised or guaranteed as part of the service delivery at an accommodation establishment. An example would include a niche hotel advising through their marketing communications that guests can expect service with a humorous twist. By making such a promise to potential guests, the service would indeed have to be based on multiple instances of humour delivered through the hotel's employees, its processes and its physical evidence to fulfil customer expectations. According to Frew (2006: 643-646) this can also be classified under formal humour in tourism. As the ladder rises, the height signifies the degree of intention or purpose of using humour as a communication tool. At the lower levels, humour is used spontaneously and is situationdependent while at the higher levels, there is a purposeful strategy to use humour to differentiate themselves from competitors and provide the guest with a memorable experience.

As Ball and Johnson (2011) noted, humour increases the "fun factor" in hospitality situations and also generates warmth, openness and trust. This was also the case in this study, where many accommodation establishments noted that the main reason why they used humour was to create positive emotions. Guests can laugh at amusing misunderstandings and use humour for coping with poor service, however it is preferable that poor service does not occur in the first place.

Two-thirds of participants who completed the accommodation guest survey think that humour is an important part of travel experience and the majority of accommodation establishment survey respondents (56.7\%) think that humour should be used in accommodation establishments. This indicates the growing importance and prevalence of humorous interactions in the accommodation sector. Cultural differences can often explain why humour appreciation varies. Therefore, when deliberately providing humour, accommodation establishments must ensure that guests are not offended, and that aggressive humour is avoided.

When staff members of accommodation establishments discover something amusing for their clients, this can often be used repeatedly for similar customer interactions. An important factor that has been stressed in the marketing literature is that a company has to know the customers' preferences. Most tourism experiences are associated with people wishing to have a good time and providing humour can help to accomplish this goal.

One possibility is to use humour left behind by previous customers. For example, if there was an amusing event or situation with one customer, these stories can also be shared with new guests. Based on the process model of communicating a humorous message (Kotler et al. 2005), it is unlikely to avoid misunderstandings because the decoding phase is based on peoples' different national and cultural backgrounds or a lack of appropriate language skills between the sender and the receiver. There is always the possibility that strategically used humour by the accommodation provider is misunderstood by a guest, which may create a negative situation where the guest feels insulted.

Tourism and hospitality are global industries. If hospitality service staff are empowered to use humour in interactions with customers, it could provide them with a comparative advantage because it allows certain companies to differentiate themselves from others in the marketplace (Pabel \& Pearce 2015). Humour can also be used by staff members of accommodation establishments as a coping mechanism in dealing with stressful situations. It not only helps the 
employees to cope with long working hours and mundane tasks, but also gives them the opportunity to share company values in a more engaging way. However, any humorous communication should not be forced, but fostered through more authentic ways (Pabel \& Pearce 2018). Having a humour-induced script to work from and learning about ways of delivering messages in enthusiastic and humorous ways can be beneficial. It is understandable that some accommodation establishments would choose not to use humour as an engagement and communication strategy because it might not fit with their intended brand image. There are also likely to be situations in which humour will not be accepted or appreciated and there are customers who will not understand humorous messages.

\section{Conclusions}

Deliberately using humour in accommodation establishments and marketing communication with the purpose of making service delivery more attractive for customers is likely to become increasingly important since customers these days wish to experience products and services in ways that are out of the ordinary (Darmer $\&$ Sundbo 2008). The aim of this paper was to investigate how humour is used in the marketing communication and service processes in accommodation establishments. Based on the findings of this study, a decision support model was developed to show how different levels of humour could be used in accommodation establishments.

Humour plays an important role in peoples' lives. The study was conducted in the context of Estonian accommodation establishments. Over a third of Estonian accommodation establishments $(87 \%)$ used humour in their marketing or services. The most common way of using humour was in one-on-one interactions with customers, i.e. through amusing stories. Many of the accommodation-based respondents provided several stories and pictures showing how humour was used by them. Likewise, many of the accommodation guest respondents provided stories about unexpected situations, often related to unprofessional service and misunderstandings that they perceived as humorous afterwards.

How could humour be used more effectively in the marketing communication and service provision of accommodation providers? Humour does not depend on star ratings or other classifications to rate the quality of accommodation, but it depends to a large extent on its human resources to deliver humorous communication. Humorous signs, pictures, and other design elements can also provide value to the overall experience. With today's wide use of social media, there is a chance to share photos of humorous decorations with the world.

It was interesting to note that even if accommodation guests appreciate and value humorous experiences while travelling, stories that were retold by respondents were often related to gaps or shortcomings in service delivery that were neutralized by humour.

There are several limitations to this study. The accommodation establishment guest survey involved a convenience sample with a relatively small sample size. Future studies assessing the use of humour in accommodation settings should aim to include larger samples that may be more representative. Future research could also involve surveys that include visual elements in order to trigger the respondents' memory and broaden responses. In the decision support model for humour usage in accommodation establishments in Figure 6, there are many different levels of humour that could be applied to accommodation establishments. The topic clearly demands further research investigating the nuances of each level in more detail and ideally, in different contexts with guests from varied cultural and linguistic backgrounds. 


\section{References}

Ball, S. \& Johnson, K. (2011). 'Humour in commercial hospitality settings', in Lashley, C. \& Morrison, A. (eds.), In Search of Hospitality: Theoretical Perspectives and Debates, London: Routledge, pp. 198-216.

Berger, J. \& Iyengar, R. (2013). 'Communication channels and word of mouth: How the medium shapes the message'. Journal of Consumer Research 40 (3), pp. 567-579.

Birch, N. (2011). 'Using humour in advertising effectively'. Grin. Retrieved September 14, 2015 from http://www.grin.com/en/e-book/269678/using-humour-in-advertising-effectively.

Brand Estonia. (2018). Retrieved November 26, 2018 from https://brand.estonia.ee/et/.

Brennan, L. \& Binney, W. (2010). 'Fear, guilt, and shame appeals in social marketing'. Journal of Business Research 63 (2), pp. 140-146.

Bryman, A. (2003). Disney \& His Worlds. London: Routledge.

Campos, A., Mendes, J., Oom do Valle, P. \& Scott, N. (2018). 'Co-creation of tourist experience: a literature review'. Current Issues in Tourism 21 (4), pp. 369-400.

Carrell, A. (2008). 'Historical views of humour'. Retrieved September 14, 2015 from http://www.humoursummerschool.org/01/articlesNhandouts/Historical_Views.pdf

Chłopicki, W. \& Laineste, L. (2019). 'Editorial. Communication styles: Between deliberate strategy and ambivalence', Journal of Pragmatics (In press).

Danish Design Centre. (2015). 'The design ladder: Four steps of design use'. Retrieved September 14, 2015 from https://danskdesigncenter.dk/en/design-ladder-four-steps-designuse.

Darmer, P. \& Sundbo, J. (2008). 'Introduction to experience creation', in Sundbo, J. \& Darmer, P. (eds.), Creating Experiences in the Experience Economy. Cheltenham, UK: Edward Elgar Publishing.

EUROSTAT (2018). 'Tourism statistics'. Retrieved November 26, 2018 from https://ec.europa.eu/eurostat/statistics-

explained/index.php/Tourism_statistics\#Tourism_.E2.80.94_demand_and_supply.

FitzPatrick, M., Davey, J., Muller, L. \& Davey, H. (2013). 'Value-creating assets in tourism management: Applying marketing's service-dominant logic in the hotel industry'. Tourism Management 36, pp. 86-98.

Freud, S. (1905). Jokes and Their Relation to the Unconscious. Vienna: F. Deuticke.

Frew, E. (2006). 'The humour tourist: A conceptualisation'. Journal of Business Research 59 (5), pp. 643-646.

Friedman, S. (2014). Comedy and Distinction. The Cultural Currency of a "Good" Sense of Humour. Abingdon Oxon: Routledge.

Friedman, S. \& Kuipers, G. (2013). 'The divisive power of humour: Comedy, taste and symbolic boundaries'. Cultural Sociology 7 (2), pp. 179-195.

Future Brand. (2014). 'Country Brand Index 2014-15'. Retrieved September 25, 2015 from http://www.futurebrand.com/cbi/2014.

Gáll, L.-K. (2011). “'Special today - No ice cream.” Accidental humour in international public notices'. The Round Table. Partium Journal of English Studies. Retrieved September 14, 2015 from http://theroundtable.partium.ro/Archive/language_studies/laura_karolina_gall_special_tod ay_no_ice_cream_accidental_humour_in_international_public_notices.doc.

Halim, N. A. A. \& Razak, N. A. (2014). 'Communication strategies of women leaders in entrepreneurship'. Procedia - Social and Behavioural Sciences 118, pp. 21-28.

Hiiumaa Tourist Info Center. (2015). 'Welcome to Hiiumaa!'. Retrieved September 8, 2015 from http://www.hiiumaa.ee/page/mainpage/25. 
Johnson, K. \& Ball, S. (2000). 'Humour and licensed retailing'. International Journal of Wine Marketing 12 (1), pp. 16-29.

Kotler, P., Jain, D. C. \& Maesincee, S. (2002). Marketing Moves: A New Approach to Profits, Growth and Renewal. Boston, MA: Harvard Business School Press.

Kotler, P., Wong, V., Saunders, J. \& Armstrong, G. (2005). Principles of Marketing. Fourth European Edition. Harlow: Pearson Education Limited.

Kuosa, T. \& Westerlund, L. (eds.). (2013). Service Design: On the Evolution of Service Expertise. Viljandi: Lahti University of Applied Sciences.

Kurtulay, Z., Taskiran, O., Cetin, G., Kizilirmak, I., Atsiz, O. \& Karayilan, E. (2015). 'Exploring the boutique hotel guest experience'. Paper presented at the International Interdisciplinary Business-Economics Advancement Conference, Las Vegas. Retrieved October 1, 2015 from http://iibaconference.org/wpcontent/uploads/4th_IIBA_Conference_Proceedings_Las_Vegas_May_2015.pdf.

LaFave, L. (1972). 'Humour judgments as a function of reference groups and identification classes', in McGhee, P. E. \& Goldstein, J. H. (eds.), The Psychology of Humour: Theoretical Perspectives and Empirical Issues, New York: Academic Press.

Dragicevich, P., Ragozin, L. \& McNaughtan, H. (2016). Lonely Planet Estonia, Latvia \& Lithuania. London: Lonely Planet Publications.

Lynch, O. H. (2002). 'Humorous communication: Finding a place for humour in communication research'. Communication Theory 12 (4), pp. 423-445.

MacKinlay, E. (2004). 'Humour: A way to transcendence in later life?'. Journal of Religious Gerontology 16 (3), pp. 43-58.

Magic Unica. (2018). 'Estonian Character'. Retrieved December 2, 2018 from http://itaaliapuhkus.ee/en/estonian-character.

Martin, R. A. (2007). The Psychology of Humour: An Integrative Approach. Burlington: Elsevier.

Martin, R. A. \& Ford, T. E. (2018). The Psychology of Humour: An Integrative Approach. San Diego, CA: Academic Press.

McGhee, P. E. (1983). 'Humour development: Toward a life span approach', in McGhee, P. E. \& Goldstein, J. H. (eds.), Handbook of Humour Research. Volume 1: Basic Issues, New York: Springer. pp. 109-134.

Murphy, J. L. (2011). 'Estonia: The country's acclaim for Depeche Mode may or may not explain so many long faces'. November 22. PopMatters. Retrieved October 1, 2015 from http://www.popmatters.com/review/149326-estonia-by-alexander-theroux/

Neuendorf, K. A. (2015). 'The four humor mechanisms'. Retrieved September 14, 2015 from https://academic.csuohio.edu/kneuendorf/c32114/c32114TheFourHumorMechanisms.doc.

Pabel, A. \& Pearce, P. L. (2015). 'Highlighting the benefits of tourism humour: The views of tourists'. Tourism Management Perspectives 16, pp. 357-364.

Pabel, A. \& Pearce, P. L. (2016). 'Tourists' responses to humour'. Annals of Tourism Research 57, pp. 190-205.

Pabel, A. \& Pearce, P. L. (2018). 'Selecting humour in tourism settings - A guide for tourism operators'. Tourism Management Perspectives 25, pp. 64-70.

Palmer, J. (1994). Taking Humour Seriously. London: Routledge.

Pearce, P. L. (2009). 'Now that is funny: Humour in tourism settings'. Annals of Tourism Research 36 (4), pp. 627-644.

Pearce, P. L. \& Pabel, A. (2015). Tourism and Humour. Bristol: Channel View Publications.

Raskin, V. (2008). The Primer of Humour Research. Berlin: Mouton de Gruyter. Retrieved October 4, 4019 from https://www.academia.edu/6196205/The_Primer_of_Humor_Research_Edited_by_Victor_ Raskin 
Republic of Estonia Ministry of Economic Affairs and Communication. (2014). 'Accommodation services'. Retrieved September 14, 2015 from https://www.mkm.ee/en/objectives-activities/tourism/accommodation-services.

Samson, A. C. \& Gross, J. J. (2012). 'Humour as emotion regulation: The differential consequences of negative versus positive humour'. Cognition and Emotion 26 (2), pp. 375384.

Seneviratne, D. \& Molesworth, B. R. C. (2015). 'Employing humour and celebrities to manipulate passengers' attention to pre-flight safety briefing videos in commercial aviation'. Safety Science 75, pp. 130-135.

Sirakaya, E., Petrick, J. \& Choi, H.-S. (2004). 'The role of mood on tourism product evaluations'. Annals of Tourism Research 31 (3), pp. 517-539.

Slivar, I., Periša, A. \& Horvat, A. (2018). 'Destination Marketing Organisations use humour and co-creation: an exploratory study from Croatia'. Interdisciplinary Description of Complex Systems 16 (2), pp. 238-248.

Šliburytė, L. \& Klimavičius, M. (2012). 'Humour appeal in advertising: how to use it effectively'. Economics and Management 17 (3).

Smuts, A. (2018). 'Humor'. September 28. Internet Encyclopedia of Philosophy. Retrieved November 26, 2018 from https://www.iep.utm.edu/humor/.

Strick, M., Holland, R. W., van Baaren, R. B., Knippenberg, A. v. \& Dijksterhuis, A. (2013). 'Humour in advertising: An associative processing model'. European Review of Social Psychology 24 (1), pp. 32-69.

Van Vliet, V. (2013). 'Service marketing mix - 7 P's'. ToolsHero. Retrieved December 2, 2018 from http://www.toolshero.com/marketing/service-marketing-mix-7ps/.

Van Vugt, M., Hardy, C., Stow, J. \& Dunbar, R. (2014). 'Laughter as social lubricant: A biosocial hypothesis about the pro-social functions of laughter and humour'. Retrieved September 24, 2018 from https://www.researchgate.net/publication/265270173_LAUGHTER_AS_SOCIAL_LUBRI CANT_A_Biosocial_Hypothesis_about_the_Prosocial_Functions_of_Laughter_and_Humor.

Visit Estonia. (2015). 'Ways of life: Traditional Estonian lifestyle'. Visitestonia.com. Retrieved September 14, 2015 from http://www.visitestonia.com/en/about-estonia/estonianculture/way-of-life-traditionalestonian-lifestyle.

Wall, G. (2017). 'Tourism and Humour (book review)'. Tourism Recreation Research 42 (4), p. 546.

Warren, C. \& McGraw, A. P. (2013). 'When humour backfires: revisiting the relationship between humorous marketing and brand attitude'. Marketing Science Institute Reports 1 (1), pp. 13-124.

Wilson, C. (1979). Jokes Form, Content, Use and Function. New York: Academic Press.

Zhang, C. X. \& Pearce, P. L. (2016). 'Experiencing Englishness: humour and guided tours'. Tourism Recreation Research 41 (3), pp. 259-271. 